\title{
COMPARATIVE ANALYSIS OF ETHNO-DEMOGRAPHIC CHARACTERISTICS OF RUTHENIAN AND UKRAINIAN NATIONAL MINORITIES IN VOJVODINA
}

DOI: https://doi.org/10.18509/AGB.2018.05

UDK: 911.3:323.15(497.113)

\author{
Milan Lalić ${ }^{1}$ \\ ${ }^{1}$ Faculty of Science, Department of Geography, tourism and hotel management, \\ University of Novi Sad, Serbia (Ph.D. student) \\ Corresponding author: dgt.milan.lalic@ @student.pmf.uns.ac.rs
}

Submitted: January 2017, Accepted: May 2017, Published: October 2017

\begin{abstract}
The Republic of Serbia is in the ethnic sense multinational community. Besides Serbs (83.32\%), Hungarians are the most numerous, followed by Roma and Bosniaks. The final results of Serbian 2011 census of population, households, and dwellings showed that in Serbia there are 21 ethnic communities whose number exceeds two thousand members. In this respect stands out Region of Vojvodina, which is one of the basic characteristics multiculturalism, or a high degree of joint habitation of different ethnic communities in the same area. In addition to the majority nation in Vojvodina live numerous national minorities differentiated in terms of demographic development, socio-economic, historical, cultural and civilizational characteristics, national emancipation and political organization.

Although represented in smaller numbers from other ethnic communities in Vojvodina, with a very small population resources, Ruthenians and Ukrainians have a very interesting folklore heritage and a variety of common, but different characteristics. Unlike the Ruthenians, who have migrated from the north-eastern counties of former Hungary in the eighteenth century, the current Ukrainians in Serbia, which mainly live in Vojvodina originate from migrations of Ukrainians from Bosnia, from the time when Bosnia and Herzegovina and Serbia were in the common state of Yugoslavia most mid-twentieth century.

The paper analyses the population dynamics, ethno-demographic changes and spatial distribution of these minorities which are characterized by spacious dispersion or ethnic compactness or as a process of ethnic homogenization caused by many factors.
\end{abstract}

Key words: Vojvodina, Ruthenians, Ukrainians, censuses, depopulation

\section{Introduction}

The Republic of Serbia is an ethnically diverse multinational society. The final results of Serbian 2011 census of population, households, and dwellings showed that in Serbia there are 21 ethnic communities whose number exceeds two thousand members. The Republic of Serbia is in the ethnic sense a multinational community. Besides Serbs (83.32\%), Hungarians are the most numerous (mostly represented in the region of Vojvodina), followed by Roma (Region of South and East Serbia and Vojvodina region) and Bosniaks (mostly living in Šumadija and Western Serbia) [1].
The region of Vojvodina, which covers the area of $21,506 \mathrm{~km}^{2}$, stands out from other parts of the country for its multi-ethnicity. It is situated in the south-eastern part of the Pannonian plain, the meeting point of the Balkans and Central Europe. The region of Vojvodina consists of three sub-regions: Bačka, Banat, and Srem. Besides the Serbs $(66.76 \%)$, members of other national minorities populate Vojvodina [2]. Their origin, tradition, culture, mother tongue, religion, and demographic features are versatile. However, excellent ethnic interrelations, ethnic and confessional tolerance, respect and rights to protection of minorities are significant for stability, demographic and dem- 
ocratic development of Vojvodina. It is due to ethnic, religious and cultural differences that the region of Vojvodina became a unique area. The most numerous minorities are Hungarians (13.00\%), Slovaks (2.60\%), Croats $(2.43 \%)$, Roma (2.19\%), Romanians (1.32\%), Montenegrins (1.15\%), and other national minorities making less than $1 \%$ of the population of Vojvodina [3].

Although represented with a rather small population potential, Ruthenians and Ukrainians who originate from the same geographical region and practice the same religion also have an interesting folklore heritage and a significant scope of similar and different characteristics. Both national minorities had been represented as one category by the 1971 population census when the census results were the following: 20,109 Ruthenians (1.03\%) and 5,006 Ukrainians $(0.25 \%)$. According to the 2011 population census data there were 13,928 Ruthenians $(0.72 \%)$ and 4,202 Ukrainians $(0.22 \%)$ in Vojvodina [3].

\section{Methodology}

The basic methodological approach used in this paper is the processing and scientific analysis of the obtained statistical data. Quantitative and qualitative analysis and comparative method were also applied as well as the fieldwork, historical method, analytical study of the literature and other materials, statistical data processing of the population censuses (1948-2011) and other secondary publications with the published data on the research topic. The documents and information used in this study were obtained from the Statistical Office of the Republic of Serbia and Provincial Secretariat for Education, Administration and National Communities of the Autonomous Province of Vojvodina, National Council of Ruthenian National Minority, National Council of Ukrainian National Minority, Demographic Monograph with the data of register books from the first two RuthenianRuski Krstur and Kucura (today most of the Ruthenian national minority in Vojvodina live there) and also Greek-Catholic church to which Ruthenians and Ukrainians belong. Certain data are presented in the form of graphs or maps for better visualization.

\section{The origin of the population and immigra- tion patterns}

Ruthenians and Ukrainians, EasternSlavonic nations, had been migrating in various historical periods and under economic circumstances to the areas in the West Balkans and the present territory of the Republic of Serbia. The borders have been moved and changed in the long period from Kievan Rus (kingdom), Tatar-Mongol conquers, the Galician-Volhynian state, The PolishLithuanian Commonwealth, the Kozak era and its end, Russian Empire, Austrian Monarchy, world wars and USSR to the modern Republic of Ukraine [4].

Systematic population migrations started in all parts of the Empire in the first half of the $18^{\text {th }}$ century when the Turks were overpowered in South-eastern Europe by Austria. The area of present Vojvodina was scarcely populated and economically undeveloped which also worsened by immigration of numerous Serbs to Russia after the abolition of Potisje-Pomorišje section of the Habsburg Military Frontier. The liberated parts were then systematically colonized by Ruthenians, Slovaks, Czechs, Hungarians, Germans, Polish and other nations [4].

Ruthenians were among the nations arriving and settling to Vojvodinian fertile land. They arrived from south-eastern counties of Hungary, from the regions that today belong to eastern Slovakia, Carpathian region in Ukraine and Hungary. January $17^{\text {th }}, 1751$ was the officially recorded day of the Ruthenian arrival to this area when the Contract on colonization of wilderness Veliki Krstur by 200 Ruthenian Greek-Catholic families was signed. Officially, those were the early days of Ruski Krstur, the oldest and most famous settlement of the Ruthenians in Vojvodina and Serbia [5].

Under similar circumstances in 1763, a document was signed in Sombor about settling Ruthenians to Kucura. Pursuant to the articles of the contract the colonists had to be Ruthenians (Rusyns), had to have the status of free people, had to belong to GreekCatholic religion (Uniats). Hardworking citizens of the two settlements in Bačka, initially 350 families and newly arrived immigrants from the old place of Gornjica ( an upper region in Austria-Hungary), developed 
the national community of Ruthenians in Vojvodina. During the second half of the $18^{\text {th }}$ century, the population of the aforementioned settlements was continuously growing. Due to the lack of the arable land in the $19^{\text {th }}$ and the early $20^{\text {th }}$ centuries, there were frequent migrations of Ruthenians from Ruski Krstur and Kucura towards the plains in Bačka and Srem, where they symbolically seeded about ten new Ruthenian settlements [5].

After the collapse of the Zaporozhian Sich, the Kozak country on the Dnieper River in 1775, Russian Empress Catherine the Great banished Kozaks from the country. They were wandering on the rims of the Turkish Empire, the banks of the Danube River, in Moldova and Tataria until they finally obtained the right to immigrate to the Empire from the Austrian Emperor Joseph II, but under unfavorable conditions (restricted freedom of movement, no right to marry, military service obligation by the old age). It is considered that there were no descendants of the second wave of Ukrainian migrants in this area [4].

The only recognizable Ukrainian national minority that today lives in Serbia did not emigrate directly from Ukraine. The present Ukrainians in Serbia, primarily in Vojvodina, originate from migrations of the Ukrainians from Bosnia, during the period when Bosnia and Herzegovina and Serbia were parts of former Yugoslavia.

Soon after the arrival of Ukrainians in Bosnia, they made individual contacts with the Ruthenians in Vojvodina. They were connected by the Greek-Catholic religion and relatively similar languages. They entered into mixed marriages, most frequently in Vojvodina. Prior to the beak out of the World War II and during it, there were individual migrations of the Ukrainians from Bosnia to the Kingdom of Serbs, Croats and
Slovenians. Generally speaking, this was not a mass phenomenon. Mass migrations of the Ukrainians from Bosnia to Serbia took place after the World War II in 1945 and 1946. The newly formed state Federal People's Republic of Yugoslavia heavily colonized Vojvodina. Among other colonists, there were several tens of Ukrainian families that arrived to various places in Vojvodina. The Ukrainians were very small ethnic group in those settlements. Migrations of the Ukrainians from Bosnia to Vojvodina driven by the idea of pursuing better living conditions were intensified in the 1950s and 1960s. Although the migrations were individual and unorganized, large numbers of Ukrainians arrived to Vojvodina and formed noticeable Ukrainian Diaspora.

Almost 70,000 refugees from Ukraine and Southern Russia found their asylum in the Kingdom of Serbs, Croats, and Slovenians during the October Revolution in Russia in the 1920s. It was estimated that among the refugees there were over 30,000 Ukrainians. Among them, there were a lot of intellectuals who had their traces left behind in education, art and culture in Serbia between the two world wars. A major portion of the Ukrainians, who immigrated to Serbia in the 1920s, emigrated to Western Europe and transoceanic countries after 1944/45 [4].

\section{Results and discussion}

Ruthenians and Ukrainians have never been strong ethnic groups in terms of numbers. According to censuses after the World War II or earlier, it was impossible to estimate the number of the Ruthenians and the Ukrainians in Vojvodina, as separate categories, since there was a unique classification group "Ruthenians-Ukrainians". It was only after the 1971 census when the population data for both ethnic groups became obtainable separately.

Table 1: Changes in the number of Ruthenians and Ukrainians in Vojvodina 1971-2011

\begin{tabular}{|c|c|c|c|c|}
\hline Censuses & $\begin{array}{c}\text { Number of Ruthenians } \\
\text { in Vojvodina }\end{array}$ & $\begin{array}{c}\text { Share in population } \\
(\%)\end{array}$ & $\begin{array}{c}\text { Number of Ukrainians } \\
\text { in Vojvodina }\end{array}$ & $\begin{array}{c}\text { Share in population } \\
(\%)\end{array}$ \\
\hline 1971 & 20,109 & 1.03 & 5,006 & 0.26 \\
\hline 1981 & 19,305 & 0.96 & 5,001 & 0.25 \\
\hline 1991 & 17,652 & 0.88 & 4,565 & 0.23 \\
\hline 2002 & 15,626 & 0.77 & 4,635 & 0.23 \\
\hline 2011 & $13, .928$ & 0.72 & 4,202 & 0.22 \\
\hline
\end{tabular}

Source: Own calculations according to the Statistical Office of the Republic of Serbia [3] 
In the observed period the number of the Ruthenians in Vojvodina decreased for $30.74 \%$ (it dropped from 20,109 to $13,928)$ and their share in the total population fell from $1.03 \%$ to $0.72 \%$. During the same period, the number of the Ukrainians in Vojvodina decreased for $16.07 \%$ (from 5,006 to 4,202) and their share in the total population decreased from $0.26 \%$ to $0.22 \%$. Such fluctuation in numbers in the observed period is the consequence of unfavorable biological characteristics (unfavorable age structure), negative natural population growth, emigration, and assimilation.

Table 2: The number of Ruthenians in the municipalities of Vojvodina, according to Census between 1971-2011

\begin{tabular}{|c|r|r|r|r|r|r|r|r|}
\hline \multirow{2}{*}{ Censuses } & \multicolumn{2}{|c|}{1971} & \multicolumn{2}{|c|}{1991} & \multicolumn{2}{|c|}{2002} & \multicolumn{2}{|c|}{2011} \\
\cline { 2 - 9 } & Number & \multicolumn{1}{c|}{$\%$} & Number & \multicolumn{1}{c|}{$\%$} & Number & \multicolumn{1}{c|}{$\%$} & \multicolumn{1}{c|}{ Number } & \multicolumn{1}{c|}{$\%$} \\
\hline Vojvodina & 20,109 & 1.03 & 17,652 & 0.88 & 15,626 & 0.77 & 13,928 & 0.72 \\
\hline Kula & 6,812 & 13.98 & 6,055 & 12.28 & 5,398 & 11.16 & 4,588 & 10.64 \\
\hline Vrbas & 4,732 & 10.88 & 4,221 & 9.10 & 3,765 & 8.21 & 3,375 & 8.02 \\
\hline Žabalj & 2,229 & 8.78 & 1,610 & 6.23 & 1,407 & 5.11 & 1,198 & 4.58 \\
\hline Novi Sad & 2,194 & 1.03 & 2,300 & 0.87 & 2,032 & 0.68 & 2,160 & 0.63 \\
\hline S. Mitrovica & 905 & 1.15 & 819 & 0.96 & 691 & 0.80 & 620 & 0.78 \\
\hline Šid & 2,139 & 5.52 & 1,515 & 4.17 & 1,318 & 3.38 & 1,027 & 3.00 \\
\hline B. Topola & 357 & 0.82 & 301 & 0.74 & 292 & 0.76 & 254 & 0.76 \\
\hline
\end{tabular}

Source: Own calculations according to the Statistical Office of the Republic of Serbia [3]

Upon their arrival to Vojvodina Ruthenians first settled in central parts of Bačka, and later due to the lack of arable land they moved to other parts of Bačka and to Srem. After the World War II a part of the Ruthenian population took part in the rural-to-urban migration. The centers of the Ruthenian population concentration in Vojvodina were central parts of Bačka, the western part of Srem and the towns around these areas [6]. According to the 2011 census, the Ruthenians did not make the majority in any of the municipalities. Majority of the Ruthenians in Vojvodina $(88 \%)$ live on the territory of the munici- palities of Kula, Vrbas, Žabalj, and Šid and the town of Novi Sad (88.66\%).

The territorial concentration of the Ukrainians differs partly from the Ruthenian population, although most of them live in the central part of Bačka in the municipalities of Kula (making almost 3\% of the total population) and Vrbas (about $2 \%$ of the total population). More than 100 Ukrainians live in the municipalities of Sremska Mitrovica and Inđija, as well as in the town of Novi Sad according to the latest census data. An interesting fact is the increase in the number of the Ukrainians in the municipality of Inđija between the 1991 and 2002 censuses [3], [6].

Table 3: The number of Ukrainians in the municipalities of Vojvodina, according to Census between 1971-2011

\begin{tabular}{|c|r|r|r|r|r|r|r|r|}
\hline \multirow{2}{*}{ Censuses } & \multicolumn{2}{|c|}{1971} & \multicolumn{2}{|c|}{1991} & \multicolumn{2}{|c|}{2002} & \multicolumn{2}{|c|}{2011} \\
\cline { 2 - 9 } & Number & \multicolumn{1}{c|}{$\%$} & Number & \multicolumn{1}{c|}{$\%$} & Number & \multicolumn{1}{c|}{$\%$} & Number & \multicolumn{1}{c|}{$\%$} \\
\hline Vojvodina & 5,006 & 0.26 & 4,565 & 0.23 & 4,635 & 0.23 & 4,202 & 0.22 \\
\hline Kula & 1,380 & 2.83 & 1,425 & 2.89 & 1,453 & 3.00 & 1,290 & 2.99 \\
\hline Vrbas & 1,089 & 2.50 & 1,031 & 2.22 & 975 & 2.13 & 836 & 1.99 \\
\hline Bač & 195 & 1.01 & 118 & 0.69 & 92 & 0.57 & 82 & 0.57 \\
\hline Novi Sad & 543 & 0.25 & 459 & 0.17 & 482 & 0.16 & 484 & 0.16 \\
\hline S. Mitrovica & 712 & 0.91 & 586 & 0.68 & 593 & 0.69 & 534 & 0.67 \\
\hline Inđija & 38 & 0.09 & 25 & 0.06 & 422 & 0.85 & 391 & 0.82 \\
\hline
\end{tabular}

Source: Own calculations according to the Statistical Office of the Republic of Serbia [3] 
Observing the structure of the settlements where the members of the two national minorities live, we may conclude that there are significant differences: the Ukrainians live predominantly in urban settlements (about 74\%), whereas the Ruthenians live predominantly in rural settlements (about 60\%) [3], [6]. This is understandable with regard to the fact that the Ruthenians were given the land upon arrival to Vojvodina, whereas the Ukrainians emigrated from Bosnia after the agrarian reform and were not given the land. They arrived without personal property and settled in industrial centers of that time such as Kula, Vrbas, Sremska Mitrovica and Inđija. The settlements with a significant share of the Ruthenian minor-

Table 4: Share of urban and other settlements to Census 2002 and 2011

\begin{tabular}{|c|r|r|r|r|}
\hline \multirow{2}{*}{ Censuses } & \multicolumn{2}{|c|}{2002} & \multicolumn{2}{|c|}{2011} \\
\cline { 2 - 5 } & Urban (\%) & Other(\%) & Urban (\%) & $\begin{array}{c}\text { Other } \\
(\%)\end{array}$ \\
\hline Vojvodina-total & 56.71 & 43.29 & 59.36 & 40.64 \\
\hline Ruthenians & 38.47 & 61.53 & 40.69 & 59.31 \\
\hline Ukrainians & 73.85 & 26.15 & 74.37 & 25.63 \\
\hline
\end{tabular}

Source: Own calculations according to the Statistical Office of the Republic of Serbia [7], [8]

Natural increase and migrations are the main factors in population changes. The data on natural increase and migrations are available only for the Ruthenians, which makes the comparison impossible. Table 5 shows the comparison of the data on aging ity in the total population are the following: Ruski Krstur (86.0\%), Kucura (47.2\%), Bikić Do (47.6\%), Đurđevo (23.3\%), Bačinci (15.6\%) and Berkasovo (14.9\%). According to the latest census data, Ruski Krstur is now the only settlement with the Ruthenian majority. Also, Kucura and Bikić Do were previously the settlements with the Ruthenian majority. All the aforementioned are rural settlements. Conversely, the Ukrainians frequently live in urban settlements such as Kula, Vrbas, Sremska Mitrovica, and Novi $\mathrm{Sad}$; but less frequently in rural settlements such as Laćarak, Kruščić, and Zmajevo [3], [6].

Table 5: Natural movement of Ruthenians and Ukrainians in Vojvodina, 2002

\begin{tabular}{|c|c|c|c|}
\hline & $\begin{array}{c}\text { Ageing } \\
\text { index }\end{array}$ & $\begin{array}{c}\text { Average age of } \\
\text { population }\end{array}$ & $\begin{array}{c}\text { Share of female } \\
\text { fertile population }\end{array}$ \\
\hline Vojvodina-total & 0.95 & 39.82 & $24.44 \%$ \\
\hline Ruthenians & 1.33 & 42.81 & $22.57 \%$ \\
\hline Ukrainians & 0.95 & 41.65 & $24.03 \%$ \\
\hline
\end{tabular}

Source: Own calculations according to the Statistical Office of the Republic of Serbia [7], [8]

Mother language together with nationality and religion is one of the key ethnocultural features in censuses. Inferiority in numbers for most of the ethnic groups has a consequence in use of minority languages only within certain communities and in index, mean age and female population fertility percentage for the Ruthenians, the Ukrainians and the total population of Vojvodina. All three indicators are unfavorable for the Ruthenians.

private communication. The legal condition for official use of the language is the number above $2 \%$ of the total population in the Republic of Serbia or $15 \%$ in local self-government [4]. 
Table 6: Number of members of the Ruthenian and Ukrainian national minorities and people whose mother tongue is Ruthenian in the Republic of Serbia, according to the Census from 1971 to 2011

\begin{tabular}{|c|r|r|r|r|r|}
\hline Censuses & \multicolumn{1}{|c|}{1971} & \multicolumn{1}{c|}{1981} & \multicolumn{1}{c|}{1991} & \multicolumn{1}{c|}{2002} & \multicolumn{1}{c|}{2011} \\
\hline Ruthenians & 20,608 & 19,757 & 18,052 & 15,905 & 14,246 \\
\hline Ruth. tongue & 19,209 & 16,215 & 16,095 & 13,458 & 11,340 \\
\hline$\%$ & 93.21 & 82.07 & 89.16 & 84.61 & 79.60 \\
\hline Ukrainians & 5,643 & 5,520 & 5,042 & 5,354 & 4,903 \\
\hline Ukr. tongue & 4,415 & 2,019 & 5,354 & 2,658 & 1,909 \\
\hline$\%$ & 78.24 & 36.58 & 64.58 & 49.65 & 38.94 \\
\hline
\end{tabular}

Source: Own calculations according to the Statistical Office of the Republic of Serbia [9]

Ruthenians speak Ruthenian language and use Cyrillic script. Ruthenian language is considered the youngest literary Slav language in Serbia, officially confirmed in 1923. The Ruthenian community has a system of the most important institutions in four domains where it guarantees rights in preserving cultural tradition, language, education, and information. Ruthenian language is in official use in six municipalities in Vojvodina where most of the Ruthenians live as well as in the Provincial authorities. Furthermore, Ruthenian language is used in education from pre-school to university education. The teaching process in Ruthenian language is conducted in three primary schools (Ruski Krstur, Kucura and Đurđevo). The percentage of students attending primary education in their mother tongue is between $43 \%$ and $50 \%$ (depending on the year). There is also a grammar school in Ruski Krstur, the only one secondary school in the world, where the teaching process is conducted in Ruthenian language. For the rest of about $49 \%$ students who do not attend education in their mother tongue, lessons of mother tongue with elements of national culture are organized [5].

According to the census data, the Ukrainian language was not introduced into official use, but the National Council created the Strategy as the base for culture, education and information domains. The teaching process is not organized in the Ukrainian language, but the language is taught as mother tongue with elements of national culture on the territory of five local self-government (Vrbas, Inđija, Kula, Novi Sad and Sremska Mitrovica) for 106 students [4].
The level of ethno-phonia is obtained by the comparison of the number of certain nation population numbers and the language they consider as their mother tongue. The Ruthenians have a high level of ethno-phonia, although it has decreased in the last 40 years from $93 \%$ to about $80 \%$. The Ukrainians have a rather small level of ethno-phonia which has dropped from $78 \%$ to $39 \%$ in the observed period [9].

Members of the Ruthenian and the Ukrainian national minorities in Vojvodina practice Greek-Catholic religion. They accept the spiritual and juridical supreme authority of the pope, cherish the eastern ceremonies and customs and use Church Slavonic prayer books. The first parish was established in Ruski Krstur in 1751. The first Bishopry was established for GreekCatholics in Croatia and the Ruthenians in Bačka in Križevci in 1777. Nowadays, regarding the organization of the church, the Ruthenians are the members of Apostolic Exarchate in Serbia and Montenegro, which was established in 2003 with the seat in Ruski Krstur. Greek-Catholic parishes for the Ukrainians in Vojvodina were formed in Vrbas (1960) and Inđija (1965), whereas Sremska Mitrovica and Novi Sad joined the existing parishes. Kula has a unique parish for both national minorities [10].

\section{Conclusion}

Ruthenians and Ukrainians, the nations who originate from the same geographical regions and practice the same religion, have a whole range of similar and different characteristics. The Ruthenians, who emigrated from north-eastern counties of 
Hungary in the $18^{\text {th }}$ century, first settled in the central part of Bačka, and at the beginning of the $19^{\text {th }}$ century moved also to the western part of Srem. It was also noticeable that they infiltrated most major towns in Bačka and Srem after the World War II. The most significant Ruthenian settlement during the whole period of their presence in this area has been Ruski Krstur, and certain significance has been assigned to Kucura and Đurđevo as well.

There were important migrations of the Ukrainians from Bosnia (where they settled in the period 1898-1901) to Vojvodina primarily for economic reasons, where they formed Ukrainian national minority during the 1950s and 1960s. The distribution of the Ukrainians was highly dispersive throughout the territory, although the highest density was observed in Kula and Vrbas, former industrial centers of central Bačka, then in Sremska Mitrovica and in Indija at the end of the $20^{\text {th }}$ century.

The Ruthenians and the Ukrainians have never been powerful ethnic groups with regard to their population numbers in Vojvodina. According to the data from censuses prior to the 1971 census, they were combined into the same category and their number was up to 23,000 people. However, in the following 40 years, the number of the Ruthenians decreased for about $30 \%$ and the number of the Ukrainians for about $16 \%$. Natural population increase of the Ruthenians and the Ukrainians does not differ from other ethnic groups in the Province of Vojvodina. Their natural birth rate has had negative values from the early 1970s.
The Ruthenians belong to the ethnic communities with the highest level of ethnophonia, although there has been a decrease in the level of concordance of nationality and mother tongue (from 93\% to under $80 \%$ ), primarily due to rural-to-urban migration, e.g. Novi Sad where there is a higher possibility of exposure to assimilation and acculturation impact. With the Ukrainians, the situation is completely different since there is a relatively small level of ethno-phonia among them and in the observed period of 40 years, the level of concordance almost halved (from $78 \%$ to $39 \%$ ). This is the consequence of the dispersive distribution of those ethnic groups and the lack of education in mother tongue.

Despite relatively favorable conditions for further development in all areas of social and public life, there has been a visible decreasing trend of the population within these two communities, which is highly prominent with the Ruthenians. We may expect further decrease in the number of the Ruthenians and the Ukrainians in the future, due to the negative natural population growth, unfavorable age structure, prominent need for migration to urban centres in search for education and employment opportunities, where there is possibility of exposure to assimilation and acculturation processes, mixed marriages, emigration of educated professionals to foreign countries as well as the opinion that religious beliefs are less important factors for a national identity [11].

\section{References}

[1] Government of the Republic of Serbia: National minorities

[2] (http://www.srbija.gov.rs/pages/article.php?id=40)

[3] Kovačević, T., Ethnic Diversity and its importance for the Vojvodina Region, Celebreting geographical diversity proceedings of the Herodot Conference in Ayvalik, Turkey, 2009.

[4] Statistical Office of the Republic of Serbia, 2011 Census of Population, Households and Dwellings in the Republic of Serbia, Population, Ethnicity, Belgrade, 2012. (pod2.stat.gov.rs/Elektronska Biblioteka2).

[5] National Council of the Ukrainian National Minority: Ukrainians in Serbia (In Serbian), (http://www.ukrajincisrbije.rs/) 
[6] National Council of the Rusyn National Minority. (www.rusini.rs/en/static/28)

[7] Kicošev, S., Some geographical and demographically characteristics of Vojvodina's Ruthenians and Ukraines, Reseaches of the Institute of geography, 26/1996, Novi Sad.

[8] Ministry for Human and Minority Rights of Serbia and Montenegro: Serbian ethnical mosaic, Belgrade, 2004. (In Serbian).

[9] Đurić, V. et al., Serbian ethnical, confessional and linguistic mosaic, Belgrade, 2014. (In Serbian).

[10] Statistical Office of the Republic of Serbia, 2011 Census of Population in the Republic of Serbia, Religion, mother tongue and ethnicity, Belgrade, 2013. (In Serbian).

[11] Žiroš, M., The Ruthenians of Bačka and Srem in their homeland and in the world (1745-1991), second volume, Greek Catholic Parish Church of St. Peter and Paul, Novi Sad, 1998. (In Ruthenian).

[12] Ramač, J., Nacionalni i verski identitet Rusina u Vojvodini, kulturni i etnički identiteti u procesu globalizacije Balkana, Niš, 2002, 146-152. 